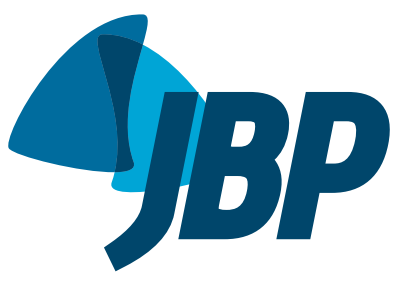

\title{
Performance of diagnostic tests for pulmonary tuberculosis in indigenous populations in Brazil: the contribution of Rapid Molecular Testing
}

\author{
Jocieli Malacarne 1,a, Alexsandro Santos Heirich 2,b, Eunice Atsuko Totumi Cunha ${ }^{3, c}$, \\ Ida Viktoria Kolte ${ }^{4, \mathrm{~d}}$, Reinaldo Souza-Santos ${ }^{4, \mathrm{e}}$, Paulo Cesar Basta ${ }^{4, \mathrm{f}}$
}

1. Instituto Nacional de Saúde da Mulher, da Criança e do Adolescente Fernandes Figueira, Fundação Oswaldo Cruz -

Rio de Janeiro (RJ), Brazil.

2. Distrito Sanitário Especial Indígena Mato Grosso do Sul - Amambai (MS), Brazil.

3. Laboratório Central de Saúde Pública, Secretaria de Estado de Saúde Campo Grande (MS), Brazil.

4. Escola Nacional de Saúde Pública Sergio Arouca, Fundação Oswaldo Cruz Rio de Janeiro (RJ), Brazil.

a. (iD) http://orcid.org/0000-0002-9845-1752

b. (D) http://orcid.org/0000-0002-9793-754X

c. (D) http://orcid.org/0000-0002-5700-9044

d. (iD http://orcid.org/0000-0003-4912-9764

e. (D) http://orcid.org/0000-0003-2387-6999

f. (ID) http://orcid.org/0000-0003-0804-0413

Submitted: 19 June 2018.

Accepted: 7 December 2018.

Study conducted in the Graduate Program in Public Health Epidemiology, Escola Nacional de Saúde Pública Sergio Arouca, Fundação Oswaldo Cruz, Rio de Janeiro (RJ), Brazil

\begin{abstract}
Objective: To evaluate the accuracy of rapid molecular testing as a diagnostic tool and estimate the incidence of smear-positive pulmonary tuberculosis among the indigenous population. Methods: This is an epidemiological study based on secondary data. We calculated the incidence of smear-positive pulmonary tuberculosis between January 1st, 2011 and December 31, 2016, and the performance of bacilloscopy and rapid molecular testing in diagnosing pulmonary tuberculosis compared to sputum culture (standard test). Results: We included 4,048 cases of indigenous people with respiratory symptoms who provided sputum samples for analysis. Among them, 3.7\%, 6.7\%, and 3.7\% had positive results for bacilloscopy, sputum culture, and rapid molecular testing, respectively. The mean incidence of pulmonary tuberculosis was $269.3 / 100$ thousand inhabitants. Rapid molecular testing had $93.1 \%$ sensitivity and $98.2 \%$ specificity, compared to sputum culture. Bacilloscopy showed $55.1 \%$ sensitivity and $99.6 \%$ specificity. Conclusions: Rapid molecular testing can be useful in remote areas with limited resources and a high incidence of tuberculosis, such as indigenous villages in rural regions of Brazil. In addition, the main advantages of rapid molecular testing are its easy handling, fast results, and the possibility of detecting rifampicin resistance. Together, these attributes enable the early start of treatment, contributing to reduce the transmission in communities recognized as vulnerable to infection and disease.
\end{abstract}

Keywords: Tuberculosis; Molecular diagnostic testing; Diagnostic tests, routine; Indians, South American.

\section{INTRODUCTION}

Tuberculosis (TB) is a severe infectious disease that affects millions of people worldwide each year, causing losses to society, especially in developing countries. In 2016, an estimated 10.4 million people fell ill with TB, 1.8 million died, and 480 thousand new cases of multidrugresistant TB (MDRTB) were reported. ${ }^{(1,2)}$

Early diagnosis and the timely start of drug therapy, associated with the search for respiratory symptomatic patients (RSPs), are considered key actions to control the disease. These actions combined have the potential to block the transmission chain and, consequently, reduce incidence and mortality rates, in addition to preventing the emergence of drug-resistant cases. ${ }^{(3)}$

The most common diagnostic tests for pulmonary TB are bacilloscopy and sputum culture. Bacilloscopy is more used for being simple, fast, and low-cost; however, its sensitivity is low, and it fails to diagnose approximately $50 \%$ of suspicious cases - particularly those that have a small bacillary load. ${ }^{(4)}$

On the other hand, sputum culture, both in solid medium (Löwenstein-Jensen and Ogawa-Kudoh) and liquid medium
(MGIT - mycobacteria growth indicator tube), is considered the standard diagnostic test, as it detects 70 to $90 \%$ of cases, and has virtually $100 \%$ specificity. Nonetheless, cultures in solid medium must be incubated at $37^{\circ} \mathrm{C}$ and observed weekly until colonies appear. In positive cases, the minimum time for diagnosis is approximately 14 days. In negative cases - when no colonies grow -, the observation period can reach 60 days (incubation period of the microorganism). ${ }^{(4)}$ The long waiting time for a conclusive culture result postpones the start of specific treatment, leading to a delay in interrupting the transmission chain, and negatively contributing to control the disease. ${ }^{(5)}$

To reduce the time to diagnosis and start of treatment, the World Health Organization (WHO) approved and recommended the use of rapid molecular testing (RMT) GeneXpert ${ }^{\circledR}$, in 2010 (CEPHEID AB Röntgenvägen 5 SE-171 54 Solna Sweden). RMT is a nucleic acid amplification test used to detect the Mycobacterium tuberculosis complex (MTBC). Its main advantages are fast results (approximately 2 hours) and identification of patients with resistance to rifampicin - one of the primary drugs in the standard treatment regimen. ${ }^{(3)}$ 
After TB control programs incorporated RMT in their routines, several validation studies have been conducted. ${ }^{(6)}$ A systematic literature review revealed that its sensitivity ranged from $72.5 \%$ to $98.2 \%$ in samples with negative and positive bacilloscopy, respectively, and its specificity was near $99.0 \%$. Also, RMT is easy to handle, safe with regard to biosafety, and not susceptible to cross-contamination. ${ }^{(6)}$

In Brazil, RMT validation studies have analyzed different scenarios and contexts; however, until now, no work was conducted among indigenous populations, recognized as vulnerable to illness.

The objective of this work was to evaluate the accuracy of RMT as a diagnostic tool among the indigenous population.

\section{METHODS}

\section{Study area and population}

The study was carried out using records of indigenous people with productive cough for 2 weeks or more - now considered RSPs - ${ }^{(7)}$ identified in the routine of the Health Care Service for Indigenous People at Polo Base Amambai, part of the Special Indigenous Health District of Mato Grosso do Sul (Distrito Sanitário Especial Indígena Mato Grosso do Sul - DSEI/MS).

This Polo Base is located in the city of Amambai, $350 \mathrm{~km}$ from the capital Campo Grande, in the southern region of the state of Mato Grosso do Sul. According to the last national census, conducted in 2010, Amambai had 34,730 inhabitants; ${ }^{(8)} 12,916$ of them were indigenous people, and most belonged to the Guarani-Kaiowá ethnicity.

Polo Base Amambai is responsible for the care of indigenous people living in the villages Amambai, Limão Verde, Taquaperi, Guassuty, and Jaguari, distributed in three different cities (Amambai, Aral Moreira, and Coronel Sapucaia) located in the region of the international border with Paraguay.

We chose this location because it concentrated the largest number of TB cases among indigenous people living in Mato Grosso do Sul( ${ }^{(9)}$ and for having a laboratory that performs bacilloscopy since 2004 and sputum cultures since 2006. In the second half of 2014, the laboratory of Polo Base Amambai received one piece of equipment that performed RMT from the Ministry of Health.

One of the goals of multidisciplinary indigenous health teams (equipes multidisciplinares de saúde indigena - EMSI) that work at DSEI/MS is to find RSPs, either by active search in the community or by care in community health centers in the villages. According to the recommended guidelines for TB control in Brazil, (7) once RSPs are identified in the community, two sputum samples must be collected. In our study area, the samples collected in the EMSI routine are sent to the laboratory of Polo Base Amambai, where they are used for bacilloscopy and RMT. Next, they are seeded in Ogawa-Kudoh medium, and stored in an oven at $37^{\circ} \mathrm{C}$. Samples from media with colony growth are sent to the Central Public Health Laboratory of Mato Grosso do Sul (Laboratório Central de Saúde Pública do Mato Grosso do Sul - LACEN/MS) to identify the MTBC and perform drug sensitivity tests. Macroscopic and microscopic examinations differentiated MTBC from nontuberculous mycobacteria (NTM). Also, the laboratory used an immunochromatographic assay to detect the presence of MTP64 in MTBC and a medium with p-nitrobenzoic acid to inhibit MTBC growth.

\section{Study Design}

We conducted a cross-sectional observational epidemiological study, which estimated the incidence of smear-positive pulmonary TB, according to the village of residence and year of notification. In addition, we analyzed the accuracy (sensitivity and specificity) of sputum bacilloscopy (January 1st, 2011 to December 31, 2016) and RMT (July 1st, 2014 to December 31, 2016), adopting the culture in Ogawa-Kudoh medium as the standard test.

\section{Inclusion and exclusion criteria}

We included all RSPs among the indigenous population who provided a sputum sample and excluded those who did not live in the coverage area of Polo Base Amambai and who had bacilloscopy and/or RMT performed to monitor the treatment of a previously diagnosed TB.

\section{Data source}

We consulted the records from the RSP investigation book from EMSI, the results of the tests performed in the laboratory of Polo Base, and population data from the demographic module of the Indigenous Health Care Information System (Sistema de Informação da Atenção à Saúde Indígena - SIASI). In addition, we checked the test results by consulting the Management System of Laboratory Environment (Sistema Gerenciador de Ambiente Laboratorial - GAL) at LACEN/MS.

\section{Study variables}

We investigated the RSP distribution according to gender, age group ( $0 \mid-10$ years; $10|-20 ; 20|-40$; $40 \mid-60 ; 60$ and + ), village of residence, and test results - sputum bacilloscopy (positive, negative, and not performed); RMT (positive, negative, and not performed), and sputum culture (positive, negative, not performed, NTM, contaminated, and no results).

\section{Data analysis}

We analyzed the data in the software Statistical Package for the Social Sciences, version 20.0 (SPSS Inc., Chicago, IL, USA). First, we assessed data completeness; next, we corrected the missing data by consulting GAL-LACEN/MS. Subsequently, we calculated incidence rates of smear-positive pulmonary TB by village and year of diagnosis. The numerator represented TB cases confirmed by sputum culture, 
and the denominator, the population at risk in each village, from year to year.

Using 2000 and 2010 census data related to indigenous ethnicity from the Brazilian Institute of Geography and Statistics (Instituto Brasileiro de Geografia e Estatística - IBGE) as a reference, we calculated the annual growth rate (a) for the city of Amambai, adopting the geometric progression method, according to the following formula:

$$
\propto=\left\{\left[\left(\mathrm{P}_{2} / \mathrm{P}_{1}\right)^{\wedge}(1 / 10)\right]-1\right\}
$$

in which $\mathrm{P}_{1}$ corresponds to the population surveyed by IBGE in 2000; and $P_{2}$, the population surveyed in 2010.

Afterward, we estimated the populations from 2011 to 2016. Population data by village were collected from the SIASI demographic module.

We conducted a descriptive data analysis, and calculated sensitivity, specificity, positive predictive value (PPV), and negative predictive value (NPV) of the first and second samples, and of them combined after sputum bacilloscopy and RMT.

\section{Ethical Aspects}

This study is part of the project Social Inequalities and Tuberculosis: Transmission, Living Conditions, and Interfaces between Biomedicine and Traditional Indigenous Medicine, approved by the Research Ethics Committee of Escola Nacional de Saúde Pública and the National Research Ethics Committee (reports $354,060$ and 650,820$)$.

\section{RESULTS}

There were 4,496 RSPs registered, from which 448 were excluded for not living in the researched villages, leaving 4,048 subjects for analysis. On average, 674 RSPs were identified annually (Table 1), corresponding to a proportion of $4.8 \%$ in the study period. The Guassuty and Limão Verde villages had the greatest percentages of RSPs, with $9.1 \%$ and $6.7 \%$, respectively.

Except for the Limão Verde village, which had a slightly higher number of men among the RSPs $(51.3 \%)$, in other villages, most RSPs consisted of women $(54.7 \%)$. The mean RSP age was 37.4 years (standard deviation: 20.5; ranging from zero to 99 years). In the Taquaperi village, $7.0 \%$ of RSPs were children aged $<10$ years (Table 2 ).

The mean annual incidence rate of pulmonary TB was 269.3/100 thousand inhabitants in the region. However, we found significant variations among the villages. In the Jaguari village, the mean incidence rate was 428.2/100 thousand, but it reached 2,420.5/100 thousand in 2012. The Amambai village had the lowest mean incidence rate (218.6/100 thousand).

Bacilloscopy was the most used test (86.7\%). However, it was also the one that presented the lowest positivity (131/3,509). In 2015 and 2016, this test had the lowest proportions of performance (35.4\% and $39.2 \%$, respectively).
In turn, sputum culture was performed in $83.3 \%$ of tests, having a mean positivity of $6.7 \%(225 / 3,370)$ in the period. The Jaguari village showed the highest positivity $(7.5 \%$ or $10 / 134)$. We underline that sputum culture was not used in $42.9 \%$ (267/663) of RSP samples in 2011 . In addition, $12.0 \%$ of samples $(405 / 3,370)$ were contaminated and 28 NTM cases $(0.8 \%)$ were detected.

From 2014 to 2016,557 RMT were carried out with a mean positivity of $3.7 \%(70 / 1,987)$. In 2016 , positivity reached $5.6 \%$ (34/610). RMT also revealed two cases with an indeterminate pattern of rifampicin resistance, but both showed negative culture results. On the other hand, a case of rifampicin resistance detected by RMT was confirmed by LACEN/MS.

After assessing all tests together (considering the first and second samples), bacilloscopy sensitivity and specificity were $55.1 \%$ and $99.6 \%$, respectively. PPV was $91.5 \%$, and NPV was $96.7 \%$. RMT reached $93.1 \%$ sensitivity and $98.3 \%$ specificity. PPV and NPV were $88.5 \%$ and $99.0 \%$, respectively (Table 3 ).

The results of the first sputum sample revealed that bacilloscopy had $46.4 \%$ sensitivity, $99.7 \%$ specificity, 90.6\% PPV, and 97.0\% NPV, while RMT presented $95.3 \%$ sensitivity, $98.5 \%$ specificity, $87.2 \%$ PPV, and 99.5\% NPV.

The result analysis of the second sample showed that bacilloscopy sensitivity increased to $79.9 \%$, and specificity decreased to $97.9 \%$, while PPV was $92.7 \%$, and NPV, 92.9\%. RMT sensitivity and specificity dropped to $86.7 \%$ and $93.7 \%$, respectively, with $92.9 \%$ PPV and $88.2 \%$ NPV.

\section{DISCUSSION}

Our findings revealed that incidence rates in the region of Polo Base Amambai are extremely high, and the number of RSPs was greater than the expected in non-indigenous populations in Brazil. ${ }^{(7)}$ RMT showed high sensitivity and specificity in detecting cases, both in the first and second sputum samples in the villages investigated. In a scenario in which TB presents high endemic levels for over a decade ${ }^{(9,10)}$ and technical, financial, and qualified human resources are scarce, RMT proved to be an excellent tool for a correct and early diagnosis, contributing to the timely start of treatment. In theory, these characteristics have the potential to block the transmission chain of the disease among this population, known for their vulnerability to TB.

The mean incidence rates revealed here were nearly eight times higher than those registered in the Brazilian population in 2016 (32.4/100 thousand inhabitants). ${ }^{(11,12)}$ Incidence rates above the national average have been reported among the indigenous populations of Mato Grosso do Sul $(9,10,13,14)$ and in the North region of the country, ${ }^{(15-20)}$, leaving no doubt that TB represents a serious public health issue among these populations. It is noteworthy that the incidence rates presented in this study concern only cases of smear-positive 
Performance of diagnostic tests for pulmonary tuberculosis in indigenous

populations in Brazil: the contribution of Rapid Molecular Testing

Table 1. Proportion of respiratory symptomatic patients (RSPs), incidence of smear-positive pulmonary tuberculosis in the villages, and diagnostic tests (bacilloscopy, rapid molecular testing, and sputum culture) performed in RSPs.

\begin{tabular}{|c|c|c|c|c|c|c|c|c|c|c|c|c|c|c|}
\hline \multirow[b]{2}{*}{$\begin{array}{l}\text { RSPs in the } \\
\text { villages }\end{array}$} & \multicolumn{2}{|c|}{2011} & \multicolumn{2}{|c|}{2012} & \multicolumn{2}{|c|}{2013} & \multicolumn{2}{|c|}{2014} & \multicolumn{2}{|c|}{2015} & \multicolumn{2}{|c|}{2016} & \multicolumn{2}{|c|}{ Total } \\
\hline & $\mathbf{n}$ & $\%$ & $\mathbf{n}$ & $\%$ & n & $\%$ & $\mathbf{n}$ & $\%$ & $\mathbf{n}$ & $\%$ & $\mathbf{n}$ & $\%$ & $\mathbf{n}$ & $\%$ \\
\hline Amambai & 204 & 2.7 & 271 & 3.5 & 321 & 4.1 & 443 & 5.5 & 370 & 4.4 & 258 & 1.7 & 1,867 & 3.9 \\
\hline Taquaperi & 236 & 7.9 & 212 & 6.9 & 173 & 5.5 & 123 & 3.8 & 143 & 4.2 & 139 & 3.1 & 1,026 & 5.3 \\
\hline Limão Verde & 130 & 8.3 & 117 & 7.3 & 94 & 5.7 & 91 & 5.3 & 96 & 5.5 & 152 & 3.6 & 680 & 6.7 \\
\hline Guassuty & 39 & 6.8 & 106 & 17.8 & 57 & 9.3 & 53 & 8.4 & 37 & 5.7 & 49 & 11.6 & 341 & 9.1 \\
\hline Jaguari & 14 & 3.9 & 41 & 11 & 46 & 12 & 14 & 3.5 & 7 & 1.7 & 12 & 14.4 & 134 & 5.7 \\
\hline Total & 623 & 4.8 & 747 & 5.6 & 691 & 5 & 724 & 5.1 & 653 & 4.5 & 610 & 0.7 & 4,048 & 4.8 \\
\hline \multicolumn{15}{|c|}{ Incidence of pulmonary tuberculosis } \\
\hline Amambai & 11 & 148.1 & 24 & 313.7 & 18 & 228.4 & 16 & 197.1 & 20 & 239.3 & 16 & 185.8 & 105 & 218.6 \\
\hline Taquaperi & 10 & 334.4 & 4 & 129.9 & 6 & 189.1 & 10 & 306.1 & 12 & 356.6 & 13 & 375 & 55 & 284.4 \\
\hline Limão Verde & 5 & 320.3 & 4 & 248.8 & 7 & 422.7 & 8 & 469 & 8 & 455.3 & 11 & 607.9 & 43 & 425.9 \\
\hline Guassuty & 7 & 1213.2 & 1 & 168.3 & 2 & 326.7 & 0 & 0 & 1 & 154 & 1 & 149.5 & 12 & 321.5 \\
\hline Jaguari & 1 & 277 & 9 & $2,420.50$ & 0 & 0 & 0 & 0 & 0 & 0 & 0 & 0 & 10 & 428.2 \\
\hline Total & 34 & 263.2 & 42 & 315.7 & 33 & 240.8 & 34 & 240.9 & 41 & 282 & 41 & 273.8 & 225 & 269.3 \\
\hline \multicolumn{15}{|l|}{ Bacilloscopy } \\
\hline Positive & 26 & 4.2 & 24 & 3.2 & 27 & 3.9 & 28 & 3.9 & 19 & 2.9 & 7 & 1.1 & 131 & 3.2 \\
\hline Negative & 575 & 92.3 & 702 & 94 & 653 & 94.5 & 681 & 94.1 & 403 & 61.7 & 364 & 59.7 & 3,378 & 83.4 \\
\hline Not performed & 22 & 3.5 & 21 & 2.8 & 11 & 1.6 & 15 & 2.1 & 231 & 35.4 & 239 & 39.2 & 539 & 13.3 \\
\hline Total & 623 & & 747 & & 691 & & 724 & & 653 & & 610 & & 4,048 & \\
\hline \multicolumn{15}{|c|}{ Rapid molecular testing } \\
\hline Positive & - & - & - & - & - & - & 6 & 0.8 & 30 & 4.6 & 34 & 5.6 & 70 & 3.5 \\
\hline Negative & - & - & - & - & - & - & 29 & 4 & 270 & 41.3 & 188 & 30.8 & 487 & 24.5 \\
\hline Not performed & - & - & - & - & - & - & 689 & 95.2 & 353 & 54.1 & 388 & 63.6 & 1430 & 72 \\
\hline Total & - & - & - & - & - & - & 724 & & 653 & & 610 & & 1987 & \\
\hline \multicolumn{15}{|l|}{ Culture } \\
\hline Positive & 34 & 5.5 & 42 & 5.6 & 33 & 4.8 & 34 & 4.7 & 41 & 6.3 & 41 & 6.7 & 225 & 5.6 \\
\hline Negative & 252 & 40.4 & 540 & 72.3 & 473 & 68.5 & 547 & 75.6 & 449 & 68.8 & 441 & 72.3 & 2702 & 66.7 \\
\hline Not performed & 267 & 42.9 & 91 & 12.2 & 111 & 16.1 & 77 & 10.6 & 88 & 13.5 & 44 & 7.2 & 678 & 16.7 \\
\hline $\begin{array}{l}\text { Nontuberculous } \\
\text { mycobacteria }\end{array}$ & 1 & 0.2 & 7 & 0.9 & 10 & 1.4 & 1 & 0.1 & 3 & 0.5 & 6 & 1 & 28 & 0.7 \\
\hline Contaminated & 69 & 11.1 & 67 & 9 & 64 & 9.3 & 65 & 9 & 72 & 11.1 & 68 & 11.1 & 405 & 10 \\
\hline No results & 0 & & 0 & & 0 & & 0 & & 0 & & 10 & 0.2 & 10 & 0.2 \\
\hline Total & 623 & & 747 & & 691 & & 724 & & 653 & & 610 & & 4048 & \\
\hline
\end{tabular}

Table 2. Age group and gender of RSPs identified in the villages

\begin{tabular}{|c|c|c|c|c|c|c|c|c|c|c|c|c|}
\hline \multirow[b]{2}{*}{$\begin{array}{c}\text { Age group, } \\
\text { years }\end{array}$} & \multicolumn{2}{|c|}{ Amambai } & \multicolumn{2}{|c|}{ Taquaperi } & \multicolumn{2}{|c|}{ Limão Verde } & \multicolumn{2}{|c|}{ Guassuty } & \multicolumn{2}{|c|}{ Jaguari } & \multicolumn{2}{|c|}{ Total } \\
\hline & $n$ & $\%$ & $n$ & $\%$ & $\mathbf{n}$ & $\%$ & $\mathbf{n}$ & $\%$ & $n$ & $\%$ & $\mathbf{n}$ & $\%$ \\
\hline $0-10$ & 83 & 4.4 & 72 & 7 & 29 & 4.3 & 16 & 4.7 & 1 & 0.7 & 201 & 5 \\
\hline $10-20$ & 324 & 17.4 & 150 & 14.6 & 114 & 16.8 & 26 & 7.6 & 34 & 25.4 & 648 & 16 \\
\hline $20-40$ & 752 & 40.3 & 424 & 41.3 & 302 & 44.5 & 132 & 38.7 & 64 & 47.8 & 1674 & 41.4 \\
\hline $40-60$ & 390 & 20.9 & 212 & 20.7 & 146 & 21.5 & 74 & 21.7 & 20 & 14.9 & 842 & 20.8 \\
\hline 60 and + & 318 & 17 & 168 & 16.4 & 88 & 13 & 93 & 27.3 & 15 & 11.2 & 682 & 16.9 \\
\hline Total & 1,867 & & 1,026 & & 679 & & 341 & & 134 & & 4,047 & \\
\hline \multicolumn{13}{|l|}{ Gender } \\
\hline Female & 1,071 & 57.4 & 537 & 52.3 & 331 & 48.7 & 202 & 59.2 & 73 & 54.5 & 2,214 & 54.7 \\
\hline Male & 796 & 42.6 & 489 & 47.7 & 349 & 51.3 & 139 & 40.8 & 61 & 45.5 & 1,834 & 45.3 \\
\hline Total & 1,867 & & 1,026 & & 680 & & 341 & & 134 & & 4,048 & \\
\hline
\end{tabular}

pulmonary TB, that is, those bacteriologically confirmed by sputum culture.
According to the epidemiological bulletin of the Ministry of Health, sputum culture was performed in only $36.6 \%$ 
Table 3. Performance of bacilloscopy and rapid molecular testing (RMT) compared to sputum culture (standard test) in the first and second sputum samples, and in both samples combined

\begin{tabular}{|c|c|c|c|c|c|c|c|}
\hline \multicolumn{8}{|c|}{ All samples } \\
\hline \multicolumn{4}{|c|}{ RMT performance } & \multicolumn{4}{|c|}{ Bacilloscopy performance } \\
\hline RMT & Positive & Negative & Total & Bacilloscopy & Positive & Negative & Total \\
\hline Positive & 54 & 7 & 61 & Positive & 97 & 9 & 106 \\
\hline Negative & 4 & 401 & 405 & Negative & 79 & 2,344 & 2,423 \\
\hline Total & 58 & 408 & 466 & Total & 176 & 2,353 & 2,529 \\
\hline Sensitivity & $93.1 \%$ & $(83.5-97.2)$ & & Sensitivity & $55.1 \%$ & $(47.7-62.2)$ & \\
\hline Specificity & $98.3 \%$ & $(96.5-99.2)$ & & Specificity & $99.6 \%$ & $(99.3-99.8)$ & \\
\hline Positive predictive value & $88.5 \%$ & & & Positive predictive value & $91.5 \%$ & & \\
\hline Negative predictive value & $99.0 \%$ & & & Negative predictive value & $96.7 \%$ & & \\
\hline \multicolumn{8}{|c|}{ First sample } \\
\hline Positive & 41 & 6 & 47 & Positive & 58 & 6 & 64 \\
\hline Negative & 2 & 385 & 387 & Negative & 67 & 2,195 & 2,262 \\
\hline Total & 43 & 391 & 434 & Total & 125 & 2,201 & 2,326 \\
\hline Sensitivity & $95.3 \%$ & $(84.5-98.7)$ & & Sensitivity & $46.4 \%$ & $(38.0-55.1)$ & \\
\hline Specificity & $98.5 \%$ & $(96.7-99.3)$ & & Specificity & $99.7 \%$ & $(99.4-99.9)$ & \\
\hline Positive predictive value & $87.2 \%$ & & & Positive predictive value & $90.6 \%$ & & \\
\hline Negative predictive value & $99.5 \%$ & & & Negative predictive value & $97.0 \%$ & & \\
\hline \multicolumn{8}{|c|}{ Second sample } \\
\hline Positive & 13 & 1 & 14 & Positive & 38 & 3 & 41 \\
\hline Negative & 2 & 15 & 17 & Negative & 10 & 132 & 142 \\
\hline Total & 15 & 16 & 31 & Total & 48 & 135 & 183 \\
\hline Sensitivity & $86.7 \%$ & $(62.1-96.2)$ & & Sensitivity & $79.9 \%$ & $(65.7-88.2)$ & \\
\hline Specificity & $93.7 \%$ & $(71.7-98.9)$ & & Specificity & $97.9 \%$ & $(93.7-99.2)$ & \\
\hline Positive predictive value & $92.9 \%$ & & & Positive predictive value & $92.7 \%$ & & \\
\hline Negative predictive value & $88.2 \%$ & & & Negative predictive value & $92.9 \%$ & & \\
\hline
\end{tabular}

of notified TB cases in Brazil, in 2015. (21), Similar results were reported in indigenous groups from other regions of the country, among which both bacilloscopy and sputum culture were underused. ${ }^{(15-17,22-24)}$

However, in our study population, the situation was quite different, given that bacilloscopy, sputum culture, and RMT were widely used in the RSP investigation, contributing to elucidate the alarming TB scenario in the region and revealing the importance of these tests for effective identification of the disease. Our findings are consistent with those reported in developed countries, such as Australia, Canada, and the United States, where sputum culture is recommended and performed in more than $90 \%$ of suspected TB cases. ${ }^{(25-27)}$

Perhaps due to the high number of tests conducted in non-ideal laboratory conditions, more than $10 \%$ of the samples sent for culture were contaminated. This rate is higher than the recommended by the TB and other mycobacteria laboratory surveillance. ${ }^{(4)}$ Nonetheless, we emphasize that other locations have shown similar results. ${ }^{(28-30)}$ The contamination could result from adverse weather conditions and inadequate storage and transportation of the samples from the villages to the laboratory. Despite this limitation, the laboratory of Polo Base Amambai had an excellent performance, being able to detect a significant number of cases in the period.

The substantial number of NTM cases diagnosed in the period is striking. However, some authors ${ }^{(31-34)}$ warn about the need to establish strict criteria to diagnose these infections, as they can cause severe clinical manifestations. For this reason, it is essential to repeat the insulation of the same agent in at least two sequential samples, in addition to determining a clinical and laboratory correlation before the NTM diagnosis. Unfortunately, our study could not establish this correlation and identify the species detected.

After evaluating the performance of bacilloscopy, we found that sensitivity was lower than $50 \%$ in the first sample and reached almost $80 \%$ in the second. This finding reinforces the need to collect two samples: one in the first visit to the health service and the other in the following morning, regardless of the outcome of the first. (7)

The RMT assessment revealed promising results regarding both sensitivity and specificity. The results shown here agree with those reported in other locations. $(6,35-38)$ We underline that this is the first time that the use of RMT was evaluated among the indigenous populations in Brazil.

With respect to costs, Pinto et al. $\left.{ }^{(39}\right)$ revealed that two sequential bacilloscopies - as recommended by the National Tuberculosis Control Program - cost approximately one RMT. Thus, we can assume that RMT is useful not only in providing accurate, cost-effective, and fast results but also in generating knowledge about rifampicin resistance and being good at estimating the presence of MDRTB. ${ }^{(3)}$ 
In spite of the evidence presented here, we need to consider some limitations. Our study analyzed data produced by the health service; therefore, a larger contingent of RSPs not identified by EMSI might exist in the community. Moreover, possible errors when filling in the records could have hidden positive results, underestimating the incidence and/or changing the accuracy of the diagnostic tests evaluated. Our group minimized these issues and increased the internal validity of the study by consulting the GAL-LACEN/MS to confirm the bacilloscopy and sputum culture results of the indigenous people evaluated.

Another limitation was the inclusion of RMT in the laboratory routine of Polo Base Amambai only in the second half of 2014, different from bacilloscopy and sputum culture, which had data available since 2011. This fact limited the analysis of a broader time-series. Also, the contamination rate of the sputum culture was relatively high, which might have hidden new cases and underestimated the incidence rates presented here.

In spite of the limitations mentioned, we believe that our results illustrate the epidemiological situation of TB among the indigenous people from the coverage area of Polo Base Amambai. In addition, the estimated RMT sensitivity and specificity in the region were similar to those reported in the specialized literature, indicating the potential of this diagnostic tool among vulnerable populations in Brazil.

Lastly, RMT can be extremely useful in remote areas, where resources are limited, and access is difficult, such as the indigenous villages in the interior of the country. In these environments, which have a high incidence of TB according to several authors, setting up a laboratory to perform sputum culture that complies with the biosafety levels required by legislation is hard. Considering this scenario, the main advantages of RMT are its easy handling, fast results, and the possibility of detecting rifampicin resistance. Together, these attributes can promote the timely start of treatment with appropriate drug regimens, contributing to reducing the transmission in communities recognized as vulnerable to illness.

\section{ACKNOWLEDGMENTS}

We would like to thank the entire team at Polo Base Amambai, the managers of DSEI Mato Grosso do Sul, and the Mycobacteria Department at LACEN/MS for the support received over the past years of working in partnership.

\section{REFERENCES}

1. World Health Organization (WHO). Global tuberculosis report 2017 [Internet]. Geneva: WHO; 2017 [cited 2019 Feb 25]. Available from: https://www.who.int/tb/publications/global_report/gtbr2017_main text.pdf

2. Silva DR, Mello FC, Kritski A, Dalcolmo M, Zumla A, Migliori GB, et al Série tuberculose. J Bras Pneumol. 2018;44(2):71-2.

3. World Health Organization (WHO). Using the Xpert MTB/RIF assay to detect pulmonary and extrapulmonary tuberculosis and rifampicin resistance in adults and children [Internet]. Geneva: WHO 2013 [cited 2019 Feb 25]. Available from: http://apps.who.int/iris/ bitstream/handle/10665/112659/WHO_HTM_TB_2013.14_eng. pdf? sequence $=1$ \&isAllowed $=y$

4. Brasil. Ministério da Saúde. Secretaria de Vigil6ancia em Saúde. Departamento de Vigilância Epidemiológica. Manual Nacional de Vigilância Laboratorial da Tuberculose e outras Micobactérias [Internet]. Brasília, DF: Ministério da Saúde [cited 2019 Feb 25]. Available from: http://bvsms.saude.gov.br/bvs/publicacoes/manual_ vigilancia_laboratorial_tuberculose.pdf

5. Kritski A, Andrade KB, Galliez RM, Maciel EL, Cordeiro-Santos M Miranda SS, et al. Tuberculosis: renewed challenge in Brazil. Rev Soc Bras Med Trop. 2018;51(1):2-6

6. Steingart KR, Schiller I, Horne DJ, Pai M, Boehme CC, Dendukur N. Xpert $®$ MTB/RIF assay for pulmonary tuberculosis and rifampicin resistance in adults. Cochrane Database Syst Rev. 2014;(1):CD009593

7. Brasil. Ministério da Saúde. Manual de recomendações para controle da tuberculose no Brasil [Internet]. Brasília, DF: Ministério da Saúde; 2011 [cited 2019 Feb 25]. Série A. Normas e Manuais Técnicos. Available from: http://bvsms.saude.gov.br/bvs/publicacoes/ manual_recomendacoes_controle_tuberculose_brasil.pdf

8. Instituto Brasileiro de Geografia e Estatística (IBGE). Sidra. Banco de Tabelas Estatísticas. Censo demográfico. Tabela 3175 - População residente, por cor ou raça, segundo a situação do domicílio, o sexo e a idade [Internet]. Brasília, DF: IBGE; 2010 [cited 2019 Feb 25] Available from: https://sidra.ibge.gov.br/Tabela/3175

9. Basta PC, Marques M, Oliveira RL, Cunha EA, Resendes AP, SouzaSantos R. Desigualdades sociais e tuberculose: análise segundo raça/cor, Mato Grosso do Sul. Rev Saúde Pública. 2013;47(5):854-64

10. Ferraz AF, Valente JG. Epidemiological aspects of pulmonary tuberculosis in Mato Grosso do Sul, Brazil. Rev Bras Epidemiol.

\section{$2014 ; 17(1): 255-66$}

11. Kritski A, Barreira D, Junqueira-Kipnis AP, Moraes MO, Campos MM Degrave WM, et al. Brazilian Response to Global End TB Strategy The National Tuberculosis Research Agenda. Rev Soc Bras Med Trop. 2016;49(1):135-45.

12. Barreira D. Os desafios para a eliminação da tuberculose no Brasil Epidemiol E Serviços Saúde [Internet]. 2018 [cited 2019 Feb 25];27(1):e00100009. Available from: http://www.scielo.br/scielo. php?script=sci_arttext\&pid=\$2237-96222018000100900\&lng=pt\&n $\mathrm{rm}=\mathrm{iso} \& \operatorname{tng}=\mathrm{pt}$

13. Croda MG, Trajber Z, Lima RC, Croda J. Tuberculosis control in a highly endemic indigenous community in Brazil. Trans R Soc Trop Med Hyg. 2012;106(4):223-9.

14. Marques AM, Pompilio MA, Santos SC, Garnês SJ, Cunha RV Tuberculose em indígenas menores de 15 anos, no Estado de Mato Grosso do Sul. Rev Soc Bras Med Trop. 2010;43(6):700-4.

15. Viana PV, Gonçalves MJ, Basta PC. Ethnic and Racial Inequalities in Notified Cases of Tuberculosis in Brazil. PLOS ONE. 2016;11(5):e0154658.

16. Belo EN, Orellana JD, Levino A, Basta PC. Tuberculose nos municípios amazonenses da fronteira Brasil-Colômbia-Peru-Venezuela: situação epidemiológica e fatores associados ao abandono. Rev Panam Salud Pública. 2013;34:321-9

17. Rios DP, Malacarne J, Alves LC, Sant'Anna CC, Camacho LA, Basta PC. [Tuberculosis in indigenous peoples in the Brazilian Amazon: an epidemiological study in the Upper Rio Negro region]. Rev Panam Salud Publica. 2013;33(1):22-9.

18. Melo TE, Resendes AP, Souza-Santos R, Basta PC. [Spatial and temporal distribution of tuberculosis in indigenous and nonindigenous of Rondônia State, Western Amazon, Brazil]. Cad Saude Publica. 2012;28(2):267-80. Portuguese.

19. Malacarne J, Rios DP, Silva CM, Braga JU, Camacho LA, Basta PC. Prevalence and factors associated with latent tuberculosis infection in an indigenous population in the Brazilian Amazon. Rev Soc Bras Med Trop. 2016;49(4):456-64

20. Levino A, Oliveira RM. [Tuberculosis among the indian population in São Gabriel da Cachoeira, Amazonas State, Brazill. Cad Saúde Pública. 2007:23(7):1728-32.

21. Brasil. Ministério da Saúde. Secretaria de Vigilância Sanitária. Indicadores prioritários para o monitoramento do Plano Nacional 
pelo Fim da Tuberculose como Problema de Saúde Pública no Brasil [Internet]. Brasília, DF: Ministério da Saúde; 2017 [cited 2019 Feb 25]. Available from: http://portalarquivos2.saude.gov.br/images/ pdf/2017/marco/23/2017-V-48-N-8-Indicadores-priorit--rios-para-omonitoramento-do-Plano-Nacional-pelo-Fim-da-Tuberculose-comoProblema-de-Sa-de-P-blica-no-Brasil.pdf

22. Mendes AM, Bastos JL, Bresan D, Leite MS. Situação epidemiológica da tuberculose no Rio Grande do Sul: uma análise com base nos dados do Sinan entre 2003 e 2012 com foco nos povos indígenas. Rev Bras Epidemiol. 2016;19(3):658-69.

23. Gava C, Malacarne J, Rios DP, Sant'Anna CC, Camacho LA, Basta PC. Tuberculosis in indigenous children in the Brazilian Amazon. Rev Saúde Pública. 2013;47(1):77-85.

24. Orellana JD, Gonçalves MJ, Basta PC. Características sociodemográficas e indicadores operacionais de controle da tuberculose entre indígenas e não indígenas de Rondônia, Amazônia Ocidental, Brasil. Rev Bras Epidemiol. 2012;15(4):714-24.

25. Robertus LM, Konstantinos A, Hayman NE, Paterson DL. Tuberculosis in the Australian Indigenous population: history, current situation and future challenges. Aust N Z J Public Health. 2011;35(1):6-9

26. Bloss E, Holtz TH, Jereb J, Redd JT, Podewils LJ, Cheek JE, et al. Tuberculosis in indigenous peoples in the U.S., 2003-2008. Public Health Rep. 2011;126(5):677-89.

27. Schneider E. Tuberculosis among American Indians and Alaska Natives in the United States, 1993-2002. Am J Public Health. 2005;95(5):873-80.

28. Rivas C, Coitinho C, Dafond V, Corbo M, Baldjian M. Performance of the Ogawa-Kudoh method for isolation of mycobacteria in a laboratory with large-scale workload. Rev Argent Microbiol. 2010;42(4):87-90.

29. Palaci M, Peres RL, Maia R, Cunha EA, Ribeiro MO, Lecco R, et al. Contribution of the Ogawa-Kudoh swab culture method to the diagnosis of pulmonary tuberculosis in Brazil. Int J Tuberc Lung Dis. 2013;17(6):782-6.

30. Jaspe RC, Rojas YM, Flores LA, Sofia Toro E, Takiff H, de Waard $\mathrm{JH}$. Evaluation of the Kudoh swab method for the culturing of
Mycobacterium tuberculosis in rural areas. Trop Med Int Health TM IH. 2009;14(4):468-71.

31. Carneiro MDS, Nunes LS, David SMM, Dias CF, Barth AL, Unis G Nontuberculous mycobacterial lung disease in a high tuberculosis incidence setting in Brazil. J Bras Pneumol. 2018;44(2):106-11.

32. Ueki SY, Martins MC, Telles MA, Virgilio MC, Giampaglia CM, Chimara $E$, et al. Micobactérias não-tuberculosas: diversidade das espécies no estado de São Paulo. J Bras Patol e Med Lab. 2005;41(1):1-8.

33. Moraes PR, Chimara E, Telles MA, Ueki SY, Cunha EA, Honer MR, et al. Identification of non-tuberculous mycobacteria from the Central Public Health Laboratory from Mato Grosso do Sul and analysis of clinical relevance. Braz J Microbiol. 2008;39(2):268-72.

34. Barreto AMW, Campos CED. Micobactérias "não tuberculosas" no Brasil. Bol Pneumol Sanitária. 2000;8(1):23-32

35. Casela M, Cerqueira SM, Casela TO, Pereira MA, Santos SO, Pozo $\mathrm{FA}$, et al. Teste rápido molecular para tuberculose: avaliação do impacto de seu uso na rotina em um hospital de referência. J Bras Pneumol. 2018;44(2):112-7

36. Pandey P, Pant ND, Rijal KR, Shrestha B, Kattel S, Banjara MR, et al. Diagnostic Accuracy of GeneXpert MTB/RIF Assay in Comparison to Conventional Drug Susceptibility Testing Method for the Diagnosis of Multidrug-Resistant Tuberculosis. PLOS ONE. 2017;12(1):e0169798.

37. Sharma SK, Kohli M, Yadav RN, Chaubey J, Bhasin D, Sreenivas V et al. Evaluating the Diagnostic Accuracy of Xpert MTB/RIF Assay in Pulmonary Tuberculosis. PLOS ONE. 2015;10(10):e0141011.

38. Chaisson LH, Roemer M, Cantu D, Haller B, Millman AJ, Cattamanchi A, et al. Impact of GeneXpert MTB/RIF assay on triage of respiratory isolation rooms for inpatients with presumed tuberculosis: a hypothetical trial. Clin Infect Dis Off Publ Infect Dis Soc Am. 2014;59(10):1353-60

39. Pinto $M$, Entringer $A P$, Steffen $R$, Trajman $A$, Pinto $M$, Entringer AP, et al. Análise de custos de um teste de amplificação de ácido nucleico para o diagnóstico da tuberculose pulmonar sob a perspectiva do Sistema Único de Saúde. J Bras Pneumol. 2015;41(6):536-8. 